\title{
British Labour Movement Solidarity in the 1913-14 Dublin Lockout
}

Abstract

While most accounts of the Dublin Lockout of 1913-14 consider it primarily as an event in Irish history, it was also one of the most important struggles in twentieth century British history. It was influenced by, and was an integral part of the great 'labour unrest' that swept over Britain in the years 1911 to 1914 and had tremendous repercussions in Britain as well as Ireland. This article provides much neglected analysis of the nature, extent and dynamics of the solidarity campaign that was generated on the British mainland for the Lockout (probably the only other comparable event was the national miners' strike of 1984-5), the reasons why such widespread support was forthcoming, and its broader implications for understanding the strengths and weaknesses of militant trade unionism in Britain during this period. It provides a comprehensive re-examination of the historical record and offers a critical analysis of existing predominant historiographical interpretations of the dispute. In the process, the article provides new insights on the potential and limits of Jim Larkin's campaign to secure sympathetic industrial action inside the British labour movement, the refusal of the Trades Union Congress (TUC) to support such an initiative, and the inability of rank-and-file and socialist militants to overcome the entrenched resistance of the official union leadership.

The Dublin lockout of $1913-14$ is the most important industrial struggle in Irish history. 25,000 workers were locked out of their place of employment by over 400 employers for refusing to sign an undertaking not to be a member of Jim Larkin's Irish Transport and General Workers' Union (ITGWU). It represented a concerted attempt to crush independent 
and militant trade union organisation within Dublin. In the past, the ITGWU's great strength had been working class solidarity whereby individual employers who found themselves in dispute with a group of workers having to confront the strength of the whole union via sympathetic strike action mobilised against them. The lockout effectively countered this, with working class solidarity now matched by employers' solidarity as the union found itself plunged into a prolonged battle of attrition designed to bleed away its resources, both financial and moral. With inspirational defiance, courage and tenacity the Dublin workers, many of them casual labourers with the lowest wages and worst living standards in Western Europe, held out for nearly six months between 26 August 1913 and 18 January 1914 in a battle of epic proportions, before finally being driven back to work defeated.

While most accounts of the Dublin Lockout consider it primarily as an event in Irish history, it was also one of the most important struggles in twentieth century British history. It was influenced by, and was an integral part of the great 'labour unrest' that swept over Britain in the years 1911 to 1914 and had tremendous repercussions in Britain as well as Ireland. ${ }^{1}$ While the embattled ITWU was stanchly nationalist, Ireland was still part of the 'United Kingdom' and the union regarded itself as part of the widespread movement of working class insurgency that was challenging employers, government and union officials in both countries. Larkin's explicit attempt to spread the dispute into the heart of the British labour movement - via the appeal to take sympathetic industrial action in support of their Dublin counterparts by refusing to handle 'tainted goods' - served to underline its ramifications. If a victory for the Dublin workers might have shaken the resolve of employers throughout Britain, the defeat of the Dublin workers only gave them encouragement. 
Yet rremarkably little detailed attention has been given to the nature, extent and dynamics of the solidarity campaign that was generated on the British mainland for the Lockout (probably the only other comparable event was the national miners' strike of 19845), the reasons why such widespread support was forthcoming, and its broader implications for understanding the strengths and weaknesses of militant trade unionism in Britain during this period. In an attempt to fill the gap, this article provides a comprehensive reexamination of the historical record (including Board of Trade Reports; Trades Union Congress (TUC) Reports; trade union archives; daily newspapers and the radical press), in the process foregrounding hitherto neglected aspects of the subject and deploying new archival findings to explore the potential and limits of Larkin's campaign to secure sympathetic industrial action inside the British labour movement.

Moreover it offers a critical analysis of existing predominant historiographical interpretations of the dispute presented by Padraig Yeates, Emmet O'Connor and others. These have claimed that Larkin's lacerating personal attacks on individual British labour movement figures for their failure to organise sympathetic industrial action was a 'fatal mistake', ${ }^{2}$ and that the decision taken at a special Trades Unions Congress (TUC) conference to refuse to agree to mobilise official trade union support for such action should not be understood as a 'betrayal' of the Dublin strikers. ${ }^{3}$

The article utilises evidence to suggest that while it was the solidarity of the British labour movement that allowed the Dublin workers to survive for as long as they did, a crucial contributory factor explaining why they went down to defeat (apart from the fierce opposition mounted by the Dublin employers backed up by the police, judiciary and Catholic Church) was the TUC's refusal to mobilise sympathetic industrial action in Britain. Such 
sympathy action (in the context of the strike unrest of 1910-13 and momentum for a campaign of industrial unity between different sections) was by no means a completely unrealistic prospect, even though whether it would have ensured a different outcome to the dispute is unknowable. Larkin's critique of British labour movement leaders must be understood within the context of his own direct experiences of trade union officialdom and his embrace of the syndicalist analysis of the limitations of union officialdom. Rank-and-file militants (and syndicalist and socialist activists generally) were too unorganised and uncoordinated to overcome the entrenched resistance of the official union leadership. This difficulty was compounded by the way Larkin's solidarity appeal fell between the alternative stools of a pure 'rank-and-filist' approach from below on the one hand (that effectively dismissed the trade union 'bureaucracy' in favour of unofficial membership action) and a primary orientation on official union action from above on the other (that effectively placed reliance on the 'bureaucracy' to mobilise membership action), rather than being orientated on a potentially more dynamic unofficial/official interplay.

\section{Solidarity Generated}

The enormous extent of the British labour movement's solidarity for the Dublin workers was expressed in a variety of ways. To begin with, there was the sheer level of financial assistance generated by the TUC and its affiliated unions, which apart from being of considerable moral comfort, was undoubtedly crucial in allowing the ITGWU to continue to fight over the long months of the Lockout. According to one estimate ${ }^{4}$ the British labour movement raised around $£ 150,000$, in today's money that would be worth over $f 11$ million. 
Most funding was donations from the TUC and its affiliated unions. The Miners' Federation of Great Britain annual conference agreed to contribute $£ 1,000$ a week, in total donating some $f 14,000$, with additional donations from many local miners' associations in Nottinghamshire, Wales and Scotland. The Amalgamated Society of Engineers donated nearly $£ 4,000$ and the National Union of Teachers contributed $£ 1,000$, with a great many other unions making single donations of $f 200-800$. The Sheet Metal Workers' Union imposed a two-shilling levy on members and the Co-operative Baking Society of Glasgow donated 900 loaves a week. The Merseyside Quay and Railway Carters' Union - an organisation composed primarily of Liverpool Protestant workers in a city marked by sectarian divide - donated $f 500$. In addition, trades councils and local union branches helped organise meetings and collections, with the London Trades Council donating $£ 573$ and Manchester and Salford Trades Council contributing $£ 205$. There were also generous financial donations made by the various different political strands within the British labour movement, such as the Independent Labour Party (ILP), the co-operative movement, and small societies, with the radical left press, in particular the Daily Herald, also raising substantial sums (albeit the newly formed Labour Party only managed to raise $f 513$ ). In addition, money was raised at general solidarity meetings and rallies and street collections, and by individual donations. ${ }^{5}$

There was also numerous specially chartered food ships (notably the SS Hare) that were sent to the Dublin strikers in very public displays of support organised under the auspices of the TUC. The ships contained thousands of packages of food, with crates of jam, tea, butter, margarine and groceries that were made up into 'family boxes'. By the time the Lockout had come to an end, the food ships had carried 1,797,699 loaves of bread, 689,166 
10lb bags of potatoes, 472,966 packets of margarine, 480,306 packets of tea, 461,530 packets of sugar, 72,830 jars of jam, 12,500 packets of cheese, 2,400 cans of condensed milk, and 884 tons of coal. ${ }^{6}$

The enthusiastic response to solidarity appeals for the Dublin workers was evidenced by the huge attendances at many public rallies held across the country which Larkin addressed as part of a 'Fiery Cross' propaganda crusade organised by an amalgam of radical left groups, including Daily Herald Leagues and Clarion Clubs. At the Free Trade Hall in Manchester there were 4,000 present, with upwards of 20,000 thronging the streets outside. ${ }^{7}$ Two huge meetings were held at the Royal Albert Hall in London, both of which were filled to capacity with 10,000 and another 10,000 gathered outside. Other meetings were held in Sheffield (2,000), Bristol $(4,000)$, Glasgow $(4,000)$, Edinburgh $(7,000)$, as well as in numerous other towns and cities. In Manchester it was reported 'the appearance of $\mathrm{Mr}$ Larkin on the platform gave rise to a remarkable demonstration. The whole audience as one mass leapt to their feet and stood cheering and shouting "Hurrah" for some minutes'. According to The Times $^{9}$ the meeting in Bristol carried a resolution supporting the Dublin workers in their struggle against employers' attempts to crush trade unionism and denounced the London-based Liberal government for 'allowing its forces to be ruthlessly used to kill, bludgeon and imprison the workers in the interests of the scoundrelly minions of capitalism'.

Larkin's arrest and seven months' imprisonment for 'seditious libel' also provoked widespread grassroots protests. An Albert Hall rally in London pledged to attend the meetings of every Liberal minister and heckle incessantly until he was released, and to campaign against the Liberals at three pending parliamentary by-elections. As a result, after 
just 17 days, and combined with the impact of rioting in Dublin, the government ordered Larkin's release. It was an unprecedented victory which helped to identify Larkin ever more closely with the Irish struggle and underlined the level of support for the Dublin workers. As the Daily Herald editorialised: 'At this stage more than ever the rank-and-file are the determining factor in the situation. They have brought about the release of Larkin and on them devolves the work of following up the victory...The spirit of the rank-and-file has been stirred to an unprecedented degree. The evidence on that point is striking' ${ }^{10}$

At the same time there was the so-called 'Kiddies Scheme' devised by the socialistfeminist Dora Montefiore in association with a group of suffragettes connected with the Daily Herald League in London, which aimed at alleviating distress by sending some of the Dublin strikers' children to stay with sympathetic families in England for the duration of the dispute. The scheme was modelled on the successful children's holiday organised by the Industrial Workers of the World during the 1912 Lawrence strike in the United States, albeit in Ireland the plan was short-circuited in the face of full-blown opposition mounted by the Catholic Church.

Most significantly, there were two bouts of rank-and-file unofficial sympathetic action by railway workers across the country. The first wave took place between 15-23 September, when the suspension of three workers at Victoria Station in Liverpool who had followed Larkin's appeal for the and boycott of Dublin exports, prompted some 3,000 railwaymen across the north west to walk out on unofficial strike, with disquiet at bonus payments in some goods yards also underlying the dispute. The strike spread to 5,500 other railway workers in Birmingham, Crewe, Derby, Sheffield, Gloucester, Nottingham and Leeds - unofficial action organised by local rank-and-file 'Vigilance' committees who campaigned 
for a national stoppage in solidarity with the ITGWU in Dublin and in support of railway workers' own grievances). ${ }^{11}$

The second wave of unofficial action by railwaymen in November occurred in the wake of Larkin's 'fiery cross' campaign, when two South Wales malgamated Society of Locomotive Engineers and Fireman (ASLEF) union train drivers employed by the Great Western Railway were sacked for refusing to run trains with coal bound for Dublin', and some 30,000 railwaymen (both ASLEF and NUR members, with goods porters striking alongside craft-minded drivers) took unofficial strike action to reverse their dismissals. Although not specifically over the Irish question the Irish dimension provided an important strand of discontent, with footplate staff also aggrieved over the demands for an 8-hour day over which a strike had been deferred just a few days earlier (Manchester Guardian, 24 November; 3 December, 1913). ${ }^{12}$

There was also solidarity action taken by some dockers in Liverpool and Salford. Sympathetic strikes took place in the Canada and Alexandra docks in north Liverpool against Irish firms that were importing strikebreakers. At the Pomona Docks in Salford, dockers on strike over union recognition agreed to suspend their dispute and unload a Guinness stout consignment on the ship SS Hare which had just arrived from Dublin, provided it also took back the food packages for the city's locked out workers. ${ }^{13}$

It was the extent and depth of the British labour movement's solidarity for the Dublin dispute, combined with Larkin's campaign for sympathetic industrial action, which secured the unprecedented agreement of the Parliamentary Committee of the TUC to call a special conference (held in December 1913 following its annual congress earlier in 
September) to consider the British trade unions' support for the Dublin dispute.This was the only occasion that such a conference had occurred since the founding of the TUC in 1868.

In sum, the support generated in Britain for the Dublin strikers represented a potent symbol of international solidarity. James Connolly, who had returned to Dublin from the United States to join Larkin as the Belfast organiser of the ITGWU, praised the trade union rank-and-file of Britain: 'I say in all solemnity and seriousness that in its attitude towards Dublin, the Working Class Movement of Great Britain reached its highest point of grandeur - attained for a moment to a realisation of that sublime unity towards which the best of us must continually aspire' ${ }^{14}$

\section{Factors Explaining the Extent of Solidarity}

There are a variety of factors that help to explain the extent of British labour movement support. The extensive coverage in the British press and cinema newsreels of the dispute and the event of 'Bloody Sunday' (when police drew batons on demonstrators and badly injured 300 people) aroused public consciousness and support among British workers who were made aware of the Dublin employers' aggressive tactics and the burden of the Lockout, on already poverty-stricken women and children.

Meanwhile TUC and affiliated unions' support for the Dublin workers also encouraged a widespread appreciation of the generalised threat to trade unionism and the right to organise. Such official union support came not merely from left-wing union leaders such as Ben Tillett (London-based Dock, Wharf, Riverside and General Labourers' Union), 
Bob Smillie (Miners' Federation) and Robert Williams (National Transport Workers' Federation), but also more moderate figures such as James Seddon (chairman of the TUC Parliamentary Committee) and Harry Gosling (chairman of the National Transport Workers' Federation) who accompanied the TUC food ships to Dublin. A notable focus of support for the Dublin workers was provided by the National Transport Workers' Federation, which brought together 16 unions catering for dockers, seamen and carters, and had played a key co-ordinating role in the London dock strike of 1912.

At the same time Larkin's 'Fiery Cross' propaganda crusade, at which his flamboyant personality and 'oratorical and rhetorical magic' were displayed, met with an enthusiastic response that 'astounded most observers and alarmed many'. ${ }^{15}$ Jack Murphy, the syndicalist Sheffield-based engineering union activist, who went on to become one of the leaders of the First World War shop stewards' movement, heard Larkin speak and recalled his impact:

Six-foot Jim Larkin, with his powerful, torrentially passionate eloquence swept the audience off its feet...I had never heard an orator of this calibre before, not seen an audience so roused to demonstrative enthusiasm...Here was the fighting leader, bearing in his person all the marks of battle, who would storm hell itself. ${ }^{16}$

Likewise the Manchester Guardian reported:

Even the most convinced and implacable opponent, if he is honest, must admit that he is a man to be reckoned with - must admit, too, that a personal influence so extraordinary must be backed by a cause or a principle that deeply moves his fellow-countrymen. ${ }^{17}$

It was not inconsequential that many sympathisers had strong Irish family connections, notably in Lancashire generally and Liverpool specifically - in the latter Larkin 
claimed 7 out of 10 people in Liverpool were a 'great part' Irish 'either by birth or blood' ${ }^{18}$ Certainly the 7,000 carters in Liverpool had a close relationship with the North of Ireland and the much larger number of dockers was correspondingly identified with the South. ${ }^{19}$ In addition, Larkin was himself from Liverpool, and had worked for some time on the docks in the city and as an organiser for the (Liverpool-based) National Union of Dock Labourers; and both Larkin and James Connolly, although Irish-based militants visited Liverpool on several occasions. ${ }^{20}$

The level of solidarity demonstrated previously by the ITGWU for British trade unionists also helps to explain the extent of support subsequently around the Dublin lockout. Significantly, not only had the ITGWU applied the doctrine of the sympathy strike within Ireland as a means of extracting concessions from employers for its own members, it had also responded to calls for solidarity action from British unions, and in doing so brought Larkin's organisation to the attention of many British workers even before the Lockout. For example, during the 1911 seaman's strike the ITGWU had gone to the rescue of the National Seamen's and Firemen's Union (NSFU), with every ship putting into the port of Dublin held up by ITGWU dockers until its crew joined the union and signed up to union conditions and rates of pay. ${ }^{21}$ Likewise, during the course of the 1911 Liverpool general transport strike, the Amalgamated Society of Railway Servants (ASRS) had called a national strike which spilled over the Irish Sea when Irish railwaymen stopped in their support; the ITGWU, acting as the ASRS's agent in Ireland, paid the railwaymen's strike pay and refused to handle 'blacked' goods. It is against this backcloth that many British union activists wanted to reciprocate; certainly the $f 500$ donated to the ITGWU by the Mersey Quay and Railway Carters' Union, an organisation composed primarily of Liverpool Protestant workers in a city all too familiar 
with religious sectarian divisions with Catholics, underlined the extent of solidarity that could be tapped, and despite Larkin's own Catholic leanings. ${ }^{22}$

There was also the broader context of the 'Labour Unrest' that had swept Britain from 1910, an unprecedented period of labour militancy with national strikes by dockers, seamen, miners, railway workers and many others, often involving unskilled, non-unionised workers. ${ }^{23}$ In each of the years 1910, 1911 and 1913 there were around 10 million days lost due to stoppages, and in 1912 (with the national miners' strike) the figure was nearly 41 million. During the four years 1910-1914 somewhere between 25-30 per cent of the British workforce went on strike, and more than 85 per cent of those who went on strike were victorious to some degree or another, underlining the way (despite the dramatic reversal of fortune in some individual battles) there was a spectacular growth in the total power of organised labour. ${ }^{24}$ Trade union organisation in Britain was completely transformed by this militancy with an increase in union membership from 2.4 million at the end of 1909 to 4.1 million by the end of 1913. It is against this backcloth of an assertive and growing trade union movement that the high level of solidarity for the Dublin dispute can be understood.

One of the most striking features of this labour militancy was its predominately unofficial character with strikers often clashing with full-time trade union officials. The perceived incorporation of such officials within formalised collective bargaining and conciliation machinery, and their reluctance to call strike action or even support disputes in which their members became involved, on the basis that this might jeopardise bargaining relations with employers, resulted in them being viewed with hostility by a wide layer of union members, with much strike activity displaying an unofficial character. As George Askwith, the Board of Trade's chief industrial commissioner, commented: 'Official leaders 
could not maintain their authority. Often there was more difference between the men and their leaders than between the latter and the employers'. ${ }^{25}$ For example, an unofficial momentum was central to the 1910 South Wales miners' strike, 1911 national railway, shipping and docks strikes, and the 1912 London docks strike. According to Jack Murphy 'to be "agin" the officials was as much a part of the nature of the syndicalist-mined workers of that time as to be "agin the Government" was a part of the nature of an Irishman'. ${ }^{26}$ Moreover, as Cronin has noted: 'the fundamental strategic innovation of 1910-1914 was the "sympathetic strike", , often used to extend the field of combat and transform sectional demands into broader ones. ${ }^{27}$ Clearly such an unofficial and solidaristic dynamic to the industrial unrest of the period helps explain the willingness of rank-and-file union members on the railways and docks to take unofficial action in support of the Dublin dispute, and for many others to be critical of trade union leader's refusal to mobilise wider sympathetic industrial action.

Another important factor was the way in which the widespread industrial unrest contributed to an implicit questioning of, and challenge to, the existing political system in Edwardian Britain, even if the attempt by historians like Halévy and Dangerfield to suggest it destroyed the liberal values on which British society had rested since the early part of the 20th century exaggerates the process. ${ }^{28}$ By contrast, the claim by Keogh and Pelling that the struggles were only really significant in terms of securing limited immediate improvements in wages and conditions and the right to union organisation, and demonstrated only trade union consciousness on the part of workers with no significant section of the working class politicised, is arguably flawed. ${ }^{29}$ In pursuing demands over terms and conditions of employment and union recognition, workers were often confronted with not only hesitant 
labour movement leaders but also intransigent employers and hostile government officials, the defiance of magistrates, and persistent violent clashes with police and troops (deployed in many disputes to protect 'blackleg' labour and/or undermine picketing). Meanwhile many workers had clearly become disaffected with parliamentary politics caused by the functioning of the Labour Party effectively acting as a mere adjunct of the post 1906 Liberal Party government. As a result, the established 'rules of the game' - piecemeal social reform by means of institutionalised collective bargaining and parliamentary action - was put under considerable strain. The realisation that strike action could win major concessions from employers reinforced the appeal of direct action as a weapon, and the willingness of different sections of workers to take sympathy industrial action with others involved in industrial disputes, exemplified by the Dublin Lockout, encouraged not only a broad awareness of class solidarity but also the development of a sense of class consciousness amongst at least a sizeable minority of workers. ${ }^{30}$

Against this backcloth the ideological and organisational influence of the radical left was also critical. While members of the two Marxist organisations, the British Socialist Party and Socialist Labour Party, mobilised support for the Dublin dispute, a more important solidarity role was played by syndicalists grouped around Tom Mann's Industrial Syndicalist Education League and the Unofficial Reform Committee of the South Wales Miners' Federation, as well associated unofficial rank-and-file amalgamation movements on the railways and in the engineering, transport and building industries, all of whom criticised the timidity of union officialdom and advocated militant unofficial 'direct action' and industrial unionism of the kind represented by the ITGWU. ${ }^{31}$ 
Clegg, Pelling and Laybourn, ${ }^{32}$ have suggested British syndicalism's role within the labour unrest was not particularly significant, while Hobsbawm asserted 'its influence was almost certainly much smaller than enthusiastic historians of the left have sometimes supposed'. ${ }^{33}$ Of course, it is true there were probably no more than a few thousand members of the ISEL at any one time, and sales of the paper The Syndicalist only reached a peak of about 20,000 readers, albeit syndicalist support for Larkinite conceptions of militant industrial unionism as a weapon for the assertion of working class economic power was also scattered among a range of activists in organisations such as the Plebs League and Central Labour College, and the Daily Herald which had a readership of between 50,000 to 150,000 . But the size and scope of the labour unrest undoubtedly provided a highly favourable context for syndicalist ideas to be broadcast, grievances identified, and workers persuaded that strike action that bypassed the perceived 'class collaboration' of official union leaders was the logical means to seek redress to both employers' pressure and state repression, and for syndicalists like Mann and others to assume leadership of strikes out of proportion to their formal numerical strength, notably in the 1910 South Wales Cambrian Combine dispute, 1911 Liverpool general transport strike, and 1914 London building workers' lockout. ${ }^{34}$

It was these working-class agitators and propagandists, who had played a key role in generating support for militant trade unionism and solidarity action generally, that were also now important in building support for the Lockout and encouraging a mood of sympathy for the aggressive syndicalist aims of the ITGWU. 


\section{Larkin's Appeal for Sympathetic Industrial Action}

We can now turn attention to Larkin's strategy to win the dispute: the call for sympathetic industrial action by the British labour movement. In light of the outright refusal of the Dublin employers to agree to any compromise settlement of the dispute (on the basis of seeking not merely the defeat but the destruction of the ITGWU and 'Larkinism'), and with shipping employers importing large numbers of strike-breakers (many of them from Britain) into Dublin to keep the port open, the ITGWU was confronted with a battle for its very existence, and it became clear that financial and food assistance from the TUC, no matter how generous, was going to win the dispute. Hence the ITGWU, Larkin argued, needed urgent solidarity industrial action in Britain. While the Daily Herald propagandised in favour of 'a general strike' in support of the Dublin workers, Larkin appealed more feasibly for solidarity 'blacking' action to secure the boycott of all goods in transit to Dublin or 'tainted goods' from Dublin that had been handled by imported scabs to break the strike.

From 1911 Larkin's syndicalist-inspired approach to trade unionism exemplified by the principle of working class solidarity via the sympathetic strike had become absolutely central to the ITGWU's body politic. As James Connolly wrote: 'The sympathetic strike is the recognition by the working class of their essential unity, the manifestation in our daily industrial relations that our brother's fight is our fight, that our sisters' troubles are our troubles, that we are all members one of another'. ${ }^{35}$ In the face of the Lockout and the attempt by employers to deny workers the right to organise, Larkin's call to 'black' Dublin goods was viewed as the most effective way to prevent the importation of non-union labour into Dublin, break the employers' solidarity, and force individual companies to settle on terms dictated by the union. Thus Larkin's crusade of meetings across Britain was used to 
attempt to secure such solidarity, notably from seamen, dockers, railwaymen and transport workers: 'We say all your money is useful, but money never won a strike. Money can't win a strike. Discipline, solidarity, knowledge of the position and the strength to carry out your will - these are the things'. ${ }^{36}$

In the process of appealing for British labour movement support, Larkin controversially castigated in a directly personalised fashion individual TUC and Labour Party leaders for their failure to agree to support the call for sympathetic industrial action. Even after the TUC agreed to call a special conference he appealed directly to the rank-and-file to bring their recalcitrant leaders to heel: 'Comrades in the British Labour movement. Your leaders suggest...that you...are prepared to back up your sympathy only in word and money value, but not in deeds. If that was correct one might feel dispirited'. He warned that union leaders were preparing a settlement of the Lockout inimical to trade union principles:

Tell your leaders now and every day until December $9^{\text {th }}$, and raise your voice upon that date to tell them that they are not there as apologists for the shortcomings of the Capitalist system, that they are not there to assist the employers in helping defeat any action of workers striving to live, nor to act as a brake on the wheel of progress. ${ }^{37}$

Larkin lambasted a number of individual trade union leaders for their refusal to support sympathetic industrial action. He called Jimmy Thomas (National Union of Railwaymen) 'a double-dyed traitor to his class' and accused Havelock Wilson (National Sailors' and Firemen's' Union) of actively assisting the Shipping Federation in pouring in strikebreakers to keep the Dublin port open. Wilson and Thomas were union leaders who had 'neither a soul to be saved nor a body to be kicked'. Likewise, in referring to Wilson and 
others, Larkin said: 'I am not going to allow these serpents to raise their foul heads and spit out their poison any longer' ${ }^{38}$

At the time such a critique was condemned by the TUC's Daily Citizen on the basis that it 'does no service to his cause, or to the cause of labour, by sowing distrust between leaders and followers'. Likewise for most labour historians ${ }^{39}$ Larkin's abuse of the British trade union leaders usually figures as one of the principal criticisms of the conduct of the dispute; it was a 'fatal mistake' that gratuitously and needlessly antagonised union officials and merely provided ammunition to his enemies. ${ }^{40}$ Some have argued that Larkin's behaviour in literally 'biting the hand that was feeding him' is to be explained psychologically in terms of Larkin's alleged 'personality dysfunction' and 'egotism'. ${ }^{41}$

Yet it is important to bear in mind that Larkin's attacks primarily reflected his own direct personal experience (as well as embrace of the general syndicalist analysis of) the limitations of trade union officialdom as being synonymous with compromise, betrayal and defeat. It was as a full-time organiser for the Liverpool-based National Union of Dock Labourers (NUDL) across ports in Ireland between 1907-8, successfully organising a series of strikes (notably by 2,500 Belfast dockers, carters and coal labourers), that Larkin's militant approach had brought him into conflict with the moderate leadership of general secretary James Sexton and his expulsion from the union, leading as a direct consequence to the formation of the ITGWU in December 1908. Such experience led him to be under no illusion that Sexton would be prepared to offer Dublin workers sympathetic industrial action, unless forced to do so by union members from below. 
Meanwhile during the Lockout Larkin observed the way that Jimmy Thomas had not only refused to support the unofficial railway workers' strikes in support of Dublin, but had instructed his striking members back to work. Likewise Larkin was aware of the way British union officials effectively assisted the Dublin employers' strikebreaking initiatives, with cargo placed by members of Sexton's NUDL on board ships manned by Wilson's National Sailors' and Firemen's Union, and then discharged in Liverpool by NUDL members. From Larkin's perspective, Thomas, Sexton, Wilson and others were betraying the Dublin workers irrespective of any biting critique he might make. Likewise Larkin's caustic remarks about the Labour Party leadership were a reflection of their emphatic opposition to the call for sympathetic industrial action, with Ramsey MacDonald (chair of the Parliamentary Labour Party) denouncing the union's key strategy: 'The sympathetic strike is poor fighting. It demoralises Trade Unionism, weakens collective action and produces reactionary prejudice in the public mind' ${ }^{42}$

More generally, Larkin was well aware of the way that during the labour unrest that had swept Britain one group of workers after another had clashed with their own trade union officials who had attempted to dampen down militancy in ways that were perceived to be detrimental to rank-and-file interests and aspirations. It was in this context that Larkin took the view that British labour movement leaders were an obstacle to his appeal for solidarity industrial action - why should officials who had betrayed their own members behave any better when it came to supporting the members of another union, and an Irish union at that? So from the very beginning Larkin attempted to raise the demand for rankand-file solidarity that it was hoped would push a reluctant and untrustworthy official union leadership into action. As we shall see, Larkin's appeal met with a favourable (albeit 
minority) response and arguably the main obstacle to solidarity action with the Dublin workers was not lack of sympathy among key groups of workers, but the opposition of the official trade union leadership.

Yet if the sharp criticism of union officials was understandable there was a question mark over what was the best way to encourage rank-and-file action that might have helped to force the hand of the officials and the TUC. Significantly there is no evidence of Larkin's call for sympathetic industrial action being anchored around targeted strategic groups of workers employed in industries involved in business with Dublin with the aim of devising an appropriate plans of action that could have linked to workers' own specific and immediate self-interested grievances on pay, conditions and union organisation. The railwaymen would have been particularly important in this respect (not least because the NUR also had members across Ireland), as would have been docks and shipping workers employed by railway companies on Irish Sea crossings. Meanwhile although some prominent full-time officials and senior lay officers of the British unions, including dockers' union leader Ben Tillett (who joined Larkin on the platform of his 'Fiery Cross' mass rallies), Robert Williams (National Transport Workers' Federation), Jack Jones (Gasworkers' and General Labourers' Union), and Robert Smillie (Scottish miners), all supported Larkin's strategy of calling for a boycott of Dublin traffic, there was no organised and systematic attempt made to forge links between rank-and-file activists and left-wing union officials to build national networks of solidarity across the unions that might have encouraged greater leverage on the TUC to act.

This raises the question: was there any serious prospect of such sympathetic industrial action gaining traction? Yeates has argued the notion of such action in Britain in support of the ITWU was utopian, ignoring the 'underlying realities' that 'many British 
unions were still recovering from three years of almost constant strikes between 1909 and 1912 that had left them weakened and, in some cases, nearly bankrupt'. ${ }^{43}$ Likewise, Williams has claimed that 'British railway and transport workers, hardly recovered from their own recent struggles, were in no position to undertake any such commitment' ${ }^{44}$

\section{Potential}

Although the number of workers involved in strikes during 1913 was less than it had been in 1911 and 1912 it was still very high at 689,000, and there was the largest number $(1,497)$ of individual strikes recorded. ${ }^{45}$ The scale of rank-and-file railway workers' militancy during this period was demonstrated in 1911 with unofficial action in Liverpool, Manchester and Sheffield forcing union officials' into calling the first ever national railway strike of over 145,000 workers over the central demands for union recognition and an end to the unsatisfactory conciliation procedures established four years earlier. The strike resulted in the rapid growth of the railway unions and a new confidence among railwaymen. ${ }^{46}$ After the strike persistent workers' discontent in 1912-13 manifested itself in a series of local unofficial disputes across the country over both immediate conditions and union recognition that further underlined the continuing gap between rank-and-file members and union officials. ${ }^{47}$ In London in August 1913 at a mass rally to celebrate the second anniversary of the 1911 strike, some 20,000 listened to a platform of unofficial speakers calling for a higher minimum wage and an 8-hour day, with several speakers declaring 'that it was no use relying on Unity House [union headquarters] - the men had to fight for 
themselves'. ${ }^{48}$ In Doncaster Jimmy Thomas was shouted down for his defence of conciliation procedures. ${ }^{49}$

In all this continuing railway unrest the influence of syndicalist ideas via leading militants such as Charles Watkins and George Brown and The Syndicalist Railwayman newspaper played an influential role. ${ }^{50}$ Indeed in his history of the NUR, Bagwell writes of this period that it became more difficult for its full-time officers to keep fully in touch with opinion in the branches where the membership was increasingly influenced by syndicalist doctrines'; the railwaymen 'were less prepared to tolerate the abuses of officialdom' ${ }^{51}$

With the outbreak of the Dublin Lockout, and following Larkin arrest and imprisonment, more than 300 NUR branches, representing some 85,000 members, passed a vote of no confidence in their leaders for tolerating 'blacklegging' and calling for a national strike in solidarity with the Dublin dispute. ${ }^{52}$ In the process, there was the possibility of linking the railwaymen's own outstanding grievances with the growing demands for solidarity with the ITGWU. The Daily Herald quoted a member of the NUR's London District Council: 'I have never seen enthusiasm as there is among our men in the London branches. They are ready for anything in the way of sympathetic action'; the only obstacle was the union leadership, but he thought it likely that 'the whole of our forces' will be 'ranged behind the men of Dublin before many days are over'. ${ }^{53}$

There was also a considerable amount of willingness to take sympathetic industrial action by dockers in different parts of the country, despite the fact they had engaged in a national strike in 1911, and London dockers had again been on strike in 1912 and sustained a crushing defeat. A leading London docks (NUDL) union official reported that: 
In all my experience I have never known a time when there has been manifested such a desire to help any union in dispute as there is among dockers both in London and the provincial ports towards their Dublin comrades. We have had to rearrange the whole of our paid officials in London, placing them in certain centres with the express purpose of preventing any disorganised move...It has been with the greatest trouble - and some of us have received rather strong words - that we have so far been able to hold the men in check. ${ }^{54}$

Likewise some other unions expressed a willingness to take sympathetic industrial action with Dublin. For example, at the Miners' Federation of Great Britain annual conference delegates supported a proposal to approach all transport unions with the aim of co-ordinating a general strike. At the TUC annual conference held in September there had been substantial disquiet at the Dublin events, further reflected in many resolutions of protest to the TUC from trades councils and union branches. The subsequent unprecedented decision by the TUC to call a special conference in November, and the numerous resolutions sent to it from union branches calling for consideration of a general 'down-tools' policy, 55 was a graphic indication of the extent of the solidarity pressure building up from below.

Meanwhile the growth of the idea of sympathetic industrial action as the means to leverage greater pressure on employers, and its widespread popularity among many rankand-file union activists, was highlighted by the way it became a powerful embedded interdependent factor in the success of shipping, transport, railway and miners' strikes between 1911 and 1912. This was most graphically displayed in the 1911 Liverpool general transport strike, with an unprecedented level of solidarity strike action taken by a wide variety of different transport workers (including seamen, railway workers, carters, tramwaymen, tugboatmen and dockers) who then took the opportunity to draw up their 
own programme of demands. The strikes climaxed in a general strike of 66,000 workers which lasted for 12 days, paralysing commercial activity across the city and compelling the employers to make enormous concessions on pay, working conditions and union recognition. ${ }^{56}$ Tom Mann commented: 'Solidarity had truly worked wonders'. ${ }^{57}$

There was the also the general appeal of industrial unionism and industrial solidarity more broadly (as advocated by the syndicalists and others) as the means to overcome the sectionalism and fragmentation of craft unions, contributing to the establishment of the National Transport Workers' Federation (NTWF) and National Union of Railwaymen (NUR). The growing rank-and-file interest in industrial unity that had developed in 1911 and 1912 encouraged the progress of official union negotiations during 1913-13 towards a permanent body linking some 1.5 million transport workers, railwaymen and miners in the form of a 'Triple Alliance' that could provide for the co-ordination of strike action between its constituent unions.

In sum, against the backcloth of a wide-scale labour unrest over the previous 2-3 years and continuing considerable unrest on the docks, railways and elsewhere, and in a context in which an underlying general feature of such unrest was its unofficial character, there was clearly some potential for the call for sympathetic industrial action over the Dublin Lockout to win widespread support. But there were also considerable obstacles to such a development that need to be considered.

\section{Limitations}


Although there was a higher number of disputes in 1913 than in the previous year, the number of strikers involved was less than in both previous years and the number of working days lost also fell commensurately in both years, plus there was less overt national conflict compared to $1911-1912 .{ }^{58}$ Meanwhile there were tremendous difficulties in attempting to convince workers who might have felt they had no direct interest in the Dublin dispute that they should refuse to do certain kinds of work in order to help fellow trade unionists. Such difficulties were compounded where it threatened victimisation and the threat of loss of permanent employment. Some activists unable to generate action on their own domestic issues may have felt reluctant to fight over the concerns of workers elsewhere, however sympathetic they may have been to Dublin. Another obstacle to solidarity industrial action for the Dublin dispute was the fact the 1912 London transport strike had been decisively defeated in a dispute that had been effectively restricted to the capital, with the failure of the National Transport Workers' Federation to secure sympathetic strike action from its members in most other ports across the country. It should also be noted that the numbers calling for sympathetic industrial action with Dublin was only a small (if not insignificant) minority of the labour movement, with the most embedded level of support generated in those areas, such as Liverpool, Bristol and south Wales, ${ }^{59}$ where the syndicalist movement had its greatest influence.

Beyond such factors most union leaders were emphatically opposed to the use of the sympathetic strike being advocated by militants within their ranks and did what they could to stymie such a development. Thomas, Sexton, and Wilson viewed spasmodic unofficial stoppages as undesirable because they were viewed as undermining their credibility with employers with whom they had struck agreements on behalf of their 
members; and they regarded sympathy strikes with particular disfavour on the basis that their priority was looking after their own members' interests, not the interests of members of other unions. In the light of the fact they had experienced tough battles with advocates of militant rank-and-file action inside their own unions, the Dublin dispute ran the risk of merely increasing such pressures with Larkin as the hero of such radicals.

The railways provided a vivid illustration of the problem. During the lockout, Jimmy Thomas, who was still seeking full recognition for his newly amalgamated union, the National Union of Railwaymen (NUR), and faced with the first wave of unofficial strike action, directly intervened in union districts in the North, the Midlands, the West and Wales to assert his authority and denounce sympathetic strike action as 'ruinous'. ${ }^{60}$ The NUR executive issued a manifesto denying that traffic from Dublin was 'blackleg traffic' and claimed that ITGWU members loaded it. NUR officials were sent to Liverpool and Birmingham to instruct their members to work their 'ordinary duties'. In the absence of official support, and widespread sympathy action elsewhere, the strikers were eventually persuaded to return to work. ${ }^{61}$

Likewise Thomas intervened to end the second wave of unofficial railwaymen's strikes in South Wales, effectively smashing the strike by instructing NUR members to do the work of the two victimised ASLEF members whom he described as 'a disgrace to the trade union movement'. ${ }^{62}$ As the NUR's semi-official historian put it: 'Mr J. H. Thomas went down and turned the table on the malcontents' ${ }^{63}$ This setback for a militant (and syndicalistinfluenced) section of workers, coming as it did three days before the TUC delegates met in London to formally consider the dispute, considerably undermined the momentum for sympathetic action. 
Other union leaders matched this opposition to solidarity action for Dublin workers, with James Sexton of the NUDL deploying officials in all the ports where it had members to discourage unofficial walkouts. Likewise the seamen's union leader Havelock Wilson publicly attacked 'Larkinism', despite the fact it had been the ITGWU that had assisted Wilson's union in their 1911 strike. And even Robert Williams (secretary of the National Transport Workers' Federation) who who had shared a 'Fiery Cross' platform with Larkin and appeared wholeheartedly committed to the cause of the Dublin workers, had second thoughts about his earlier call for a boycott of Dublin on the basis of misplaced confidence that the TUC special conference would take action to support the ITGWU.

In the meantime, even though on the face of it the Triple Alliance amounted to a significant step towards industrial unionism, for many trade union officials involved it was not seen as a means of promoting class unity through sympathetic strike action, still less a revolutionary weapon to overthrow capitalism as the syndicalists advocated. Rather it was seen merely as a means of equipping themselves with greater bargaining leverage whereby mere threats of strike action could force employers to make concessions and the government to intervene, thereby preventing or reducing spontaneous unofficial outbursts of rank-and-file militancy and sympathetic action. ${ }^{64}$ In practice, the existence of a union officialdom that acted as a brake on membership militancy was a more fundamental problem than sectionalism or the problems of union structure on which the syndicalists concentrated their attention. ${ }^{65}$

Crucially the rank-and-file unofficial action taken by railway workers in support of the Dublin dispute was too limited and isolated to be an effective counterweight to the determination of the union officials. And even where other union members expressed a 
willingness to take action, they lacked the confidence to do so independently of their own union officials, and instead awaited official direction and a lead from the TUC. There was an insufficient level of rank-and-file cross-industry organisation that could initiative and coordinate action from below across the trade union movement. This was compounded by the fact that the syndicalist and socialist left were not well organised in mobilising across industries to overcome the officials' dead hand and proved unable to mobilise broader unofficial solidarity action for Dublin. When Tom Mann went away to America in August 1913 on an extended speaking tour during the critical early weeks of the Lockout, it meant the syndicalists lost a charismatic and influential agitator who straddled the official/unofficial union divide within the labour movement, and who might otherwise have played a pivotal role. The fragmentation and disintegration of the ISEL during the summer of 1913 over strategic and organisational divisions further exacerbated the problem.

Nonetheless, despite these weaknesses, if the TUC had issued a call for sympathetic industrial action, it seems reasonable to assume (albeit unknowable) it could have potentially transformed the situation - accentuating the positives and diminishing the negatives - by encouraging those rank-and-file activists who did not have the confidence and strength to deliver such action on their own but may have been prepared to take action if they had been given an official lead.

\section{TUC 'Betrayal'}

Despite calling an unprecedented special conference to consider the British trade unions' continuing support for the Dublin dispute, the TUC ended up decisively voting against 
sympathetic industrial action by a majority of $11-1$, deploring and condemning the 'unfair' attacks upon British trade union officials, and expressing confidence in those who had been 'unjustly assailed'. ${ }^{66}$ As a result of this TUC decision the momentum for unofficial action was decisively crushed and the Dublin workers, left to struggle on isolated, eventually went down some weeks later to crushing defeat, with hundreds falling victim to the blacklist and those who retained their jobs only returning on humiliating terms. Although the ITGWU survived as an organisation, the movement of working class revolt in Ireland was decisively defeated (albeit wartime conditions were to allow a remarkable recovery from 1917-1923) and the tide of 'Larkinism' turned back. As James Connolly commented:

We asked for the isolation of the capitalists of Dublin, and for answer the leaders of the British labour movement proceeded calmly to isolate the working class of Dublin...And so we Irish workers must go down into Hell, bow our backs to the lash of the slave drive...and eat the dust of defeat and betrayal. $^{67}$

More generally, the defeat of the Lockout was also a serious blow to the British labour movement, underlined by the subsequent building workers' lockout of early 1914.

Why did the TUC special conference refuse to mobilise sympathetic industrial action? In some respects this can be explained in terms of the nature of the organisation of the conference. Although Yeates has acknowledged TUC leaders 'rigged the debate', he argues that given Larkin's 'ferocious fiery cross campaign of the proceeding weeks, it is hard to blame them' ${ }^{68}$ But in many respects the conference arrangements were stacked against Larkin's position. None of the delegates were formally elected or mandated for the occasion, instead they were either appointed by their executives or chosen from the delegation who had previously been elected to the annual TUC some three months earlier, 
with the result that they were not reflective of the growing clamour for solidarity action beyond funds and food that had gathered pace. ${ }^{69}$ In addition, delegates were only accepted from TUC affiliated unions, a decision which not only excluded the engineers' union (which had not paid its dues that year) and the National Transport Workers' Federation (which was not a trade union in its own right, even though it was composed of 29 unions that were affiliated to the TUC), but also many Irish trade unions. This meant the conference was 'largely made up of the obedient official element of their own stamp', thereby enabling the TUC leadership to evade engagement with rank-and-file support for the Lockout (albeit it was largely the same composition as the September TUC conference that had been so supportive of the Dublin workers). ${ }^{70}$

Did the TUC 'betray' the Dublin strikers? On the one hand, according to Yeates 'there is no reason to doubt the good faith of the TUC'; 'it is certainly a mistake to portray the TUC's action as some sort of betrayal of the Dublin men'. ${ }^{71}$ The TUC's Parliamentary Committee had no constitutional power to call for any kind of sympathetic industrial action in support of the Dublin workers (unlike in 1926 when the TUC General Council, which had replaced the Parliamentary Committee in 1921, called a General Strike in support of the miners' union). In addition many TUC leaders felt that sympathetic action would be costly in terms of depleting unions' strike funds, would disrupt existing bargaining arrangements with employers, open up the prospect of putting their unions into constant dispute, fritter away their members' power fighting other workers' battles without any real benefits to themselves, and anyway be ineffective compared to securing a compromise settlement with the Dublin employers. In addition, as we have seen, many officials were wary of unleashing rank-and-file membership militancy inside their own unions that they would be unable to 
control (having barely kept control amidst the whirlwind of strikes since 1911), and of a victory for 'Larkinism' increasing support for the syndicalist objectives they were so opposed to.

But arguably to understand what happened we also can draw on the sophisticated British syndicalist critique of official trade unionism, to which Larkin subscribed, and which located their alleged 'betrayal' in relation to their distinct social position. Thus the syndicalists highlighted the existence of a conservative social stratum of full-time union officials and the fundamental conflict of interest between the interests of this 'bureaucracy' and their rank-and-file members. They drew attention to the collaborationist logic of formalised collective bargaining and conciliation procedures that encouraged an attachment to the need for compromise in negotiations, the avoidance of strikes, and a commitment to the existing social and political order. It was for this reason that union officials acted as a brake on workers' struggles, betrayed their members in strikes and prevented a decisive challenge to the employers and government. ${ }^{72}$

Ironically it was Ben Tillett, one of the most prominent 'left-wing' leaders who had appeared on the platform alongside Larkin on a number of occasions during his 'fiery cross' campaign, who struck the fatal blow at the TUC special conference, proposing a motion condemning Larkin's attacks on the leaders of the British trade union movement and thereby opening the floodgates for a score of attacks on Larkin from moderates like Thomas. 
Yet notwithstanding its attempt to understand the limitations of trade-union officialdom and to suggest the practical means of overcoming its influence, Larkin and the syndicalist tradition were also confronted with some difficult dilemmas.

\section{Side-tracking of Larkin}

Newsinger ${ }^{73}$ has argued that following the 18 November announcement of a special TUC special conference to be held on 9 December, Larkin made a tactical error by not spending the next three weeks going over the officials' heads to appeal directly for immediate unofficial rank-and-file industrial action from below to boycott Dublin traffic as a means of forcing the TUC's hand ahead of the conference. From this somewhat counter-factual perspective, only if they had been confronted by a powerful unofficial movement spreading across the country, outside of their control and acting independently, would trade union officialdom have been under sufficient pressure that they felt it necessary, however reluctantly, to put themselves at the head of such a movement and give a lead from the front. Instead, Larkin was side-tracked into seeing the priority as calling on his supporters to regard the special conference as decisive, with all his energy and emphasis placed on encouraging the TUC to call official sympathetic action from above at some future date. In the event, not only were the TUC leaders not willing to undertake such a course of action, but they effectively saw the conference as a means of killing off unofficial action while preparing a compromise settlement of the Lockout.

Although we can only speculate, it seems doubtful whether Newsinger's alternative unofficial approach would have had - on its own at least - sufficient depth, scale and impact, 
such that TUC leaders would have been 'carried along by the momentum of the movement' as he suggests. By contrast possibly a more appropriate roadmap might have been the adoption of neither pure 'rank-and-filism' nor a total reliance on official union action (with Larkin effectively switching from the former optimistic approach to the latter pessimistic one), but a more dynamic interplay between continuing to try to foster unofficial action from below, while seeking to forge concrete links with sympathetic prominent left-wing trade union officials, and utilising such official/unofficial networks as the means to encourage broader levels of official union support at the TUC conference.

Certainly the attempt to obtain official endorsement from the TUC conference for the call for solidarity industrial action could be justified on the basis that official union backing, even if in practice it had subsequently only emanated from some strategically placed figures in a minority of unions and fell short of obtaining full TUC backing, could potentially have influenced a much wider layer of workers than Larkin's appeal on its own was ever liable to have. In turn this might have then boosted the confidence of activists to mobilise and the willingness of the rank-and-file to respond. As the labour unrest had vividly demonstrated, although many union officials had often been opposed, or reluctant, to call strike action, the fact that they sometimes had was a reflection of the significant counterpressures to which they felt subject from their own union activists/members. In mobilising workers on occasions it then opened up possibilities for the rank-and-file to draw in much larger numbers and escalate the action outside of the officials' control. ${ }^{74}$ But such a dynamic unofficial/official interplay was not to be realised in the Dublin Lockout. 


\section{Weaknesses of Rank-and-File and Socialist Organisation}

As will have become apparent, the lack of effective sympathetic industrial action for the Dublin strikers cannot entirely be put down to the limitations of trade union officialdom; there were also the weaknesses of rank-and-file and socialist organisation. Notwithstanding the enormous sympathy for Dublin workers inside the British labour movement and the willingness of a significant minority across the country to support Larkin's call for solidarity industrial action, there was not sufficient levels and extent of confidence for the rank-andfile to act en masse on their own. In this context it was understandable that militant activists tended to place their hopes in the official TUC leadership delivering action, despite the undeveloped official/unofficial networks that might have helped to facilitate this process.

At the same time rank-and-file militancy and anger was neither organised nor provided with a political direction by the syndicalist and socialist militants within the movement in a fashion that might also have contributed to overcoming the hesitation or opposition of union officials. In a period when the Labour Party was a marginal force and was wracked by internal dissension, the labour unrest and trade union explosion provided some basis for a renewal of socialist politics beyond the merely parliamentary form, but this was not to occur. While there were important differences between the Independent Labour Party and British Socialist Party, what they had in common was a focus on parliamentary and local government elections which meant they were ill-fitted to respond to a strike wave whose very essence was extra-parliamentary. By contrast, while the Socialist Labour Party had a serious industrial orientation, it had little direct influence outside of Scotland and was severely handicapped by its sectarianism - with its advocacy of root-and-branch opposition to all existing unions and the construction of new revolutionary unions. ${ }^{75}$ 
Not surprisingly the failure of the socialist parties to find an adequate response to the labour unrest led an increasing number of industrial activists to abandon organised socialist politics for syndicalism. But notwithstanding its success in pulling together a network of militants across different industries, the ISEL was characterised by its decentralised, localised and diffuse nature; it had no organisation and leadership structure to speak of beyond Tom Mann and a few of his confidantes. In effect it existed to propagandise, to spread the ideas of syndicalism, but devoted comparatively few resources to attempting to organise their supporters, and by the autumn of 1913 and the Lockout bitter internal divisions had culminated in the rapid disintegration of the organisation. ${ }^{76}$

Moreover the syndicalists were handicapped by their overall approach to the unions. They were confident it would be possible to transform the structures and procedures of union organisation (towards industrial unionism) as a means to wrest effective control away from bureaucratic officialdom and encourage unions to adopt revolutionary objectives. Emphasis was placed on rank-and-file democracy, decentralisation of union power and mass participation as the chief means by which the members could assert control over the official apparatus of the unions and direct it to their own ends. A militant rank-and-file, committed to direct action and grassroots union democracy, would be able to force incumbent union officials either to act in the interests of their members or be pushed aside from below. Many of these ideas were presented in a more fully rounded critique of union officialdom in the widely read pamphlet The Miners' Next Step, published by the Unofficial Reform Committee within the South Wales Miners' Federation in 1912. Yet detailed advice on the manner in which officials (including left-wingers) could manoeuvre, the difference between their rhetoric and action, the need to build links with sympathetic officials but avoid placing 
any reliance on their leadership, and the type of demands that could be placed on them (or how to build up rank-and-file organisation that could both support them where appropriate while being able to act independently of them if necessary) were not really considered. ${ }^{77}$

In addition there was the problem of the syndicalists' ideological anti-leadership stance, which influenced their antipathy towards providing an alternative revolutionary leadership to that of union officialdom. Significantly, the latter's deficiencies were blamed not on poor direction and wrong-headed policies but on the institution of leadership itself. From the fact that shopfloor workers tended to become corrupted once they were elected to full-time union office, syndicalists concluded that all leadership, whether from official or unofficial sources, was bound to stifle the independence and initiative of the rank-and-file. Of course when workers in various industries took strike action without the sanction of their union officials, syndicalists were often able and willing to give a lead. But their main effort did not involve attempting to construct an alternative leadership to that of union officialdom as such, but rather to direct this militancy into the reconstruction of the unions on a more democratic, class-wide and revolutionary basis. ${ }^{78}$ Not until the First World War and the rise of the Shop Stewards and Workers' Committee Movement did British syndicalism begin to recognise the need for independent rank-and-file organisation in competition with existing union officials. ${ }^{79}$

\section{Conclusion}

In conclusion Yeates has argued the Dublin Lockout was: 'unquestionably a tragedy', and an unnecessary one, and yet, like all tragedies, it was almost inevitable' ${ }^{80}$ Arguably this view is 
not justified. Although a devastating defeat, the Lockout also stands as a vivid example of workers' defiance, courage and tenacity, combined with the importance of inspirational leadership and militant tactics. Crucially it was the solidarity of the British labour movement that allowed the Dublin workers to survive for as long as they did. But if the strikers' fighting endurance proved unable to overcome the united front mounted by the Dublin employers (backed up by the full weight of the police, judiciary and Catholic Church), the other crucial factor in the equation contributing to its defeat was undoubtedly the lack of effective sympathetic industrial action in Britain and limitations of rank-and-file and socialist organisation to overcome the entrenched resistance of the official union leadership.

\section{Notes}

${ }^{1}$ Newsinger, 'Jim Larkin, Syndicalism and the 1913 Dublin Lockout', 3; Whitson, 'The 1913 Dublin Lockout and the British and International Labour Movements'.

2 Yeates, Lockout, 435; O’Connor, James Larkin, 45-46; Larkin, James Larkin, 132-133.

${ }^{3}$ Yeates, Lockout, 538.

${ }^{4}$ Moran, '1913, Jim Larkin and the British Labour Movement', 44.

5 Sweeney, 'The Dublin Lockout, 1913'; Yeates, Lockout, 321-323.

${ }^{6}$ Newsinger, Jim Larkin and the Great Dublin Lockout of 1913, 50.

${ }^{7}$ Holton, British Syndicalism 1900-1914, 194; Coates and Topham, The Making of the Labour Movement, 484.

${ }^{8}$ Daily Post and Mercury, 17 November 1913.

${ }^{9}$ The Times, 25 November 1913.

${ }^{10}$ Daily Herald, 15 November 1913.

${ }^{11}$ Holton, British Syndicalism, 191; Cole and Arnot, Trade Unionism on the Railways, 34-35; Liverpool Daily Post and Mercury, 10-23 September 1913 
12 Holton, British Syndicalism, 192-193; Griffiths, Driven by Ideals, 62; Manchester Guardian, 24 November 1913; 3 December 1913.

13 Yeates, Lockout, 183.

${ }^{14}$ Forward, 9 February 1914.

${ }^{15}$ Cockburn, Union Power, 45.

${ }^{16}$ Murphy, New Horizons, 38.

17 Yeates, Lockout, 414.

18 The Times, 12 November 1913.

${ }^{19}$ Mann, Tom Mann's Memoirs, 212.

${ }^{20}$ Holton, British Syndicalism, 127.

${ }^{21}$ Daily Herald, 6 December 1913.

${ }^{22}$ Smith, "'A Proud Liverpool Union"'.

${ }^{23}$ Board of Trade, 1912.

${ }^{24}$ Williams, Magnificent Journey, 272.

${ }^{25}$ Askwith, Industrial Problems and Disputes, 177.

${ }^{26}$ Murphy, New Horizons, 81.

27 Cronin, Industrial Conflict in Modern Britain, 100.

${ }^{28}$ Halévy, A History of the English People; Dangerfield, The Strange Death of Liberal England. 29 Keogh, The Rise of the Irish Working Class, 3-4; Pelling, A History of British Trade Unionism, 164.

${ }^{30}$ Meacham, "'The Sense of an Impending Clash"', 1351-4.

${ }^{31}$ Holton, British Syndicalism; Darlington, 'British Syndicalism and Trade Union Officialdom'.

32 Clegg, A History of British Trade Unions since 1889, 22-74; Pelling, A History of British Trade Unionism, 130; Pelling, 'The Labour Unrest, 1911-14'; Laybourn, A History of British Trade Unionism c1770-1990, 119.

${ }^{33}$ Hobsbawm, 'The 1970s: Syndicalism Without Syndicalists', 273.

34 Bagwell, The Railwaymen; Brown, 'Introduction', Holton, British Syndicalism; Holton, 'Syndicalism and Labour on Merseyside, 1906-14'; Darlington, 'Syndicalism and Strikes, Leadership and Influence'.

${ }^{35}$ Connolly, The Re-Conquest of Ireland.

${ }^{36}$ Freeman's Journal, 10 December 1913. 
${ }^{37}$ Daily Herald, 22 November 1913.

38 Coates and Topham, Making of the Labour Movement, 486; Yeates, Lockout, 434-5;

Freeman's Journal, 26 November 1913; Larkin, James Larkin, 132.

${ }^{39}$ For example, Yeates, Lockout, 435; O’Connor, James Larkin, 45-46; Larkin, James Larkin, 132-133.

${ }^{40}$ Larkin, James Larkin, 142.

${ }^{41}$ Desmond Greaves, The Irish Transport and General Workers' Union, 131; O'Connor, James Larkin, 70-71.

${ }^{42}$ Daily Herald, 10 September 1913.

43 Yeates, 'The Dublin 1913 Lockout', 5.

${ }^{44}$ Williams, Magnificent Journey, 268.

${ }^{45}$ Board of Trade, 1912; 1913; 1914.

${ }^{46}$ Howell, 'The Contribution of Direct Action to Gradualism'.

${ }^{47}$ Cole and Arnot, Trade Unionism on the Railways; Bagwell, The Railwaymen.

48 The Times, 18 August 1913.

${ }^{49}$ Holton, British Syndicalism, 165.

50 Holton, British Syndicalism; Gordon, '1911: The First National Railway Strike and the Rail Union Amalgamation Movement'.

${ }^{51}$ Bagwell, The Railwaymen, 337.

52 Yeates, Lockout, 304; 377.

53 Daily Herald, 10 November 1913.

${ }^{54}$ Liverpool Daily Post and Mercury, 18 November 1913; Holton, British Syndicalism, 193.

55 TUC Parliamentary Committee, 18 November 1913.

56 Taplin, 'The Liverpool General Transport Strike, 1911'; O’Brien, 'The Liverpool Transport Strike of 1911'.

57 Tom Mann's Memoirs, 212.

${ }^{58}$ Board of Trade, 1911; 1912; 1913.

${ }^{59}$ Clegg, History of British Trade Unions, 55-6; Tillett, History of the London Transport Strike of 1911; Lovell, Stevedores and Dockers; Taplin, The Dockers' Union.

${ }^{60}$ Blaxland, J.H. Thomas, 85.

${ }^{61}$ Holton, British Syndicalism, 191; Liverpool Daily Post and Mercury, 7 November 1913. 
62 Daily Herald, 10 December 1913.

63 Alcock, Fifty Years, 475.

${ }^{64}$ Clegg, History of British Trade Unions, 114-115.

${ }^{65}$ Darlington, Radical Unionism, ??

66 TUC Report, 1914.

${ }^{67}$ Forward, 9 February 1914.

68 Yeates, Lockout, 583.

${ }^{69}$ Moran, '1913', 44.

${ }^{70}$ Ryan, 'The Struggle of 1913', 176.

71 Yeates, Lockout, 583.

72 Darlington, 'British Syndicalism'.

${ }^{73}$ Newsinger, Rebel City, 97-98; Jim Larkin and the Great Dublin Lockout of 1913, 66-68.

${ }^{74}$ Darlington, 'Strike Waves, Union Growth and the Rank-and-File/Bureaucracy Interplay'.

${ }^{75}$ Hinton, Labour and Socialism

${ }^{76}$ Hinton, The First Shop Stewards' Movement.

77 Darlington, Radical Unionism, 261-264.

78 lbid.

${ }^{79}$ Hinton, First Shop Stewards' Movement.

80 Yeates, Lockout, 581.

\section{References}

Alcock, George. Fifty Years of Railway Trade Unionism. London: Co-Operative Printing Society, 1922.

Askwith, Lord. Industrial Problems and Disputes. Brighton: Harvester Press, 1974.

Bagwell, Philip. The Railwaymen: The History of the National Union of Railwaymen. London: Allen and Unwin, 1963.

Blaxland, Gregory. J.H. Thomas: A Life for Unity. London: Fredrick Muller, 1964. 
Board of Trade. Report on Strikes and Lockouts, 1912; 1913; 1914.

Brown, Geoff. 'Introduction', The Industrial Syndicalist. Nottingham: The Russell Press, 1974.

Church. Roy. 'Edwardian Labour Unrest and Coalfield Militancy, 1890-1914'. The Historical Journal 30, no. 4 (1987): 841-857.

Clegg, Hugh. A History of British Trade Unions since 1889: Vol. 2: 1911-1933. Oxford: Clarendon Press, 1985.

Coates, Ken and Tony Topham. (1994) The Making of the Labour Movement: The Formation of the Transport and General Workers' Union 1870-1922, Nottingham: Spokesman, 1994.

Cockburn, Claud. Union Power: The Growth and Challenge in Perspective. London: William Kimber, 1976.

Cole, George Douglas Howard and Robin Page Arnot. Trade Unionism on the Railways. London: Fabian Research Department, 1917.

Cole, George Douglas Howard. A Short History of the British Working Class Movement: 17891947. London: Allen and Unwin, 1960.

Connolly, James. The Re-Conquest of Ireland. Dublin: Maunsel Roberts, 1915.

Cronin, James. Industrial Conflict in Modern Britain. London: Croom Helm, 1979.

Dangerfield, George. The Strange Death of Liberal England. London: Serif, 1997.

Darlington, Ralph. 'British Syndicalism and Trade Union Officialdom'. Historical Studies in Industrial Relations no. 25/26 (2008): 103-140. 
Darlington, Ralph. 'Syndicalism and Strikes, Leadership and Influence: Britain, Ireland, France, Italy, Spain, and the United States'. International Labor and Working Class History no. 83 (2013a): 37-53.

Darlington, Ralph. Radical Unionism: The Rise and Fall of Revolutionary Syndicalism. Chicago: Haymarket Books, 2013b.

Darlington, Ralph. 'Strike Waves, Union Growth and the Rank-and-File/Bureaucracy Interplay: Britain 1889-1890, 1910-1913 and 1919-1920'. Labor History 55, no. 1 (2014): 120.

Desmond Greaves, Charles. The Irish Transport and General Workers' Union: The Formative Years: 1909-1923. London: Gill and Macmillan, 1982.

Devine, Francis. 'The Irish Transport and General Workers' Union and the Labour Unrest in Ireland, 1911'. Historical Studies in Industrial Relations 33 (2012): 169-188.

Fox, Richard Michael. Smokey Crusade. London: Hogarth Press, 1938.

Gordon, Alex. '1911: The First National Railway Strike and the Rail Union Amalgamation Movement'. Historical Studies in Industrial Relations 33 (2012): 127-147.

Gordon, Alex. Unity is Strength: The National Union of Railwaymen - 100 Years of Industrial Unionism. London: RMT, 2013.

Griffiths, Robert. Driven by Ideals: A History of ASLEF. London: Associated Society of Locomotive Engineers and Firemen, 2005.

Halévy, Elie. A History of the English People, Vol. 2: 1905-1914. London, 1961. 
Haynes, Mike. 'The British Working Class in Revolt: 1910-1914'. International Socialism, 22 (1984): 87-116.

Hinton, James. The First Shop Stewards' Movement. London: Allen and Unwin, 1976.

Hinton, James. Labour and Socialism: A History of the British Labour Movement 1867-1974. Brighton: Wheatsheaf Books, 1983.

Hobsbawm, Eric. 'The 1970s: Syndicalism Without Syndicalists' in Eric Hobsbawm (ed.) Workers: Worlds of Labour. London, 1984.

Holton, Bob. Syndicalism and Labour on Merseyside, 1906-14'. In Building the Union: Studies on the Growth of the Workers' Movement: Merseyside, 1756-1967, edited by Harold. R. Hikens. Liverpool Toulouse Press (1973): 121-150.

Holton, Bob. British Syndicalism 1900-1914: Myths and Realities. London: Pluto Press, 1976.

Howell, David. Respectable Radicals: Studies in the Politics of Railway Trade Unionism. Aldershot: Ashgate, 1999.

Howell, David. 'The Contribution of Direct Action to Gradualism: The Railway Strike of 1911'. Historical Studies in Industrial Relations 33 (2012): 61-96.

Keogh, Dermot. The Rise of the Irish Working Class: The Dublin Trade Union Movement and Labour Leaders 1890-1914. Belfast: Appletree Press, 1982.

Larkin, Emmet. James Larkin: Irish Labour Leader, 1876-1947. London: Routledge and Kegan Paul, 1965.

Laybourn, Keith. A History of British Trade Unionism c1770-1990. Stroud: Sutton Publishers, 1997. 
Lovell, John. Stevedores and Dockers: A Study of Trade Unionism in the Port of London, 18701914. London: Macmillan, 1969.

Mann, Tom. (1967) Tom Mann's Memoirs (London: Macgibbon and Kee).

Meacham, Standish. "The Sense of an Impending Clash": English Working Class Unrest before the First World War'. The American Historical Review 77, no. 5 (1972): 1343-64.

Moran, Bill. '1913, Jim Larkin and the British Labour Movement'. Saothar 4 (1978): 35-49.

Murphy, John Thomas. New Horizons. London: John Lane, 1941.

Newsinger, John. 'Jim Larkin, Syndicalism and the 1913 Dublin Lockout'. International Socialism 25 (1984): 3-36.

Newsinger, John. Rebel City: Larkin, Connolly and the Dublin Labour Movement. London: Merlin Press, 2004.

Newsinger, John. Jim Larkin and the Great Dublin Lockout of 1913. London: Bookmarks, 2013.

O'Brien, Mark. 'The Liverpool Transport Strike of 1911: "Overcomings", Transformations, and the "New Mentalities" of the Liverpool Working Class'. Historical Studies in Industrial Relations 33 (2012): 39-60.

O’Connor, Emmet. James Larkin. Cork University Press, 2002.

Pelling, H. (1968) 'The Labour Unrest, 1911-14', in Popular Politics and Society in Late Victorian Britain (London; Macmillan), pp. 147-164. 
Pelling, Henry. A History of British Trade Unionism. London: Penguin, 1987).

Postgate, Robert W. The Builders' History. London: National Federation of Building Trades Operatives, 1923.

Ryan. William Patrick. 'The Struggle of 1913: An Overview', in D. Nevin (ed.) James Larkin: The Lion of the Fold. Dublin: Gill and Macmillan (2006): 169-178.

Smith, Paul. "'A Proud Liverpool Union": The Liverpool and District Carters' and Motormen's Union, 1889-1946: Ethnicity, Class and Trade Unionism'. Historical Studies in Industrial Relations 16 (2003): pp. 1-38.

Sweeney, Jimmy. 'The Dublin Lockout, 1913: The Response of British Labour'. Saother, 6 (1980): pp. 104-108.

Taplin, Eric. The Dockers' Union: A Study of the National Union of Dock Labourers, 18891922. Leicester University Press, 1985.

Taplin, Eric. 'The Liverpool General Transport Strike, 1911'. Historical Studies in Industrial Relations, 33 (2012): 25-38.

Tillett, Ben. History of the London Transport Strike of 1911. London: National Transport Workers' Federation, 1912.

Trades Union Congress Report, 1914; 1915. London: TUC.

Whitson, Colin. (2013) 'The 1913 Dublin Lockout and the British and International Labour Movements', in Francis Devine (ed.) A Capital in Conflict: Dublin City and the 1913 Lockout. Dublin City Council (2013): 27-56. 
Williams, Francis. Magnificent Journey: The Rise of the Trade Unions. London: Odhams Press, 1954.

Yeates, Padraig. Lockout: Dublin 1913. Dublin: Gill and Macmillan, 2000.

Yeates, Padraig. 'The Dublin 1913 Lockout'. History Ireland 9, no. 2 (2001): 1-7. 